\title{
Summaries
}

Thomas Hinz und Simone Wagner

\section{Gib und Nimm. Lokale Austauschnetzwerke zwischen Marktergänzung und sozialer Bewegung}

Seit Jahren kennzeichnet Deutschland ein sehr hohes Niveau an Arbeitslosigkeit. Angesichts dieser Entwicklung erscheint für bestimmte Teilgruppen der Bevölkerung eine Rückkehr zu haushaltlicher Eigenarbeit nahe liegend. Die Strukturverschiebungen im Zuge der Modernisierung führten jedoch gerade im Bereich der Selbstversorgung zu einer Dequalifizierung. Daher diskutiert dieser Beitrag, in wie weit Tauschringe die Selbstversorgungsmöglichkeiten privater Haushalte stärken und als Quellen der Wohlfahrtsproduktion dienen können. Obwohl Tauschringe den Markt keineswegs ersetzen, können sie das marktliche Angebot dennoch sinnvoll ergänzen. Da Tauschringe möglicherweise auch sozialpolitische Funktionen übernehmen können, konzentriert sich dieser Artikel außerdem auf die Entstehungsursachen und Verbreitung von Tauschringen und auf Faktoren, die Stabilität und Überleben der Systeme gewährleisten.

\section{Give and Take. Local Exchange Networks: supplement of markets and social movement}

In recent years there have been persistently high rates of unemployment in Germany. For mitigating the negative consequences of unemployment, informal economic activity seems an appropriate and valuable means. However due to modernization and structural changes the skills for engaging in homework decreased continuously. Thus this article discusses the potential of LET-Systems - a sophisticated form of barter - to facilitate self-help amongst the unemployed and as a source of welfare production. Though LET-Systems do not replace the formal market they can complement the market's supply in a reasonable way. As LETSystems may overtake social political functions this article focuses on reasons for emergence and spreading of those systems and on mechanisms guaranteeing the systems' stability and survival.

\section{Daniel Mügge}

\section{Der blinde Fleck der zweiten Moderne. Globale Finanzmärkte und die Theorie reflexiver Modernisierung}

Finanzmärkte stellen für die Theorie reflexiver Modernisierung einen Sonderfall dar. Auf der einen Seite sind sie seit ihrem Entstehen reflexiv, haben also menschliches Handeln anstelle einer ihm äußeren Natur als Gegenstand. Auf der anderen Seite wird diese Reflexivität nach wie vor durch eine gesellschaftliche Praxis negiert die sich vertrauensvoll auf eine Trennung zwischen transzendenten Marktkräften und immanenter Finanzmarktpolitik stützt. Anhand der sogenannten Asienkrise 1997/98 lässt sich nicht nur die >diskursive Reinigung< von >natürlichen Marktkräften< illustrieren sondern auch zeigen, wie diese sich in einer Technokratisierung von globaler Finanzmarktpolitik niederschlägt.

Gleichzeitig werfen Finanzmärkte ein neues Licht auf die Theorie reflexiver Modernisierung selbst. Womöglich sind sie nicht die Ausnahme, die die Regel bestätigt, dass Gesellschaftsbereiche eine erste und eine zweite Moderne durchlaufen. Vielmehr scheint es, als ob die Reflektionsresistenz des Finanzmarktgeschehens und der Wirtschaft allgemein teil des Fundaments ist auf dem reflexive Modernisierung aufbaut. Sie werden damit zum blinden Fleck der zweiten Moderne. 


\section{The blind spot of second modernity. Global finance and the theory of reflexive modernisation}

For the theory of reflexive modernization, financial markets are a case apart. On the one hand they have been reflexive since their very existence, having human action as their object rather than an external >nature <. On the other hand, social practice continues to ignore this reflexivity and leans on a distinction between transcendent >market forces< and >immanent financial market policy< instead. The so-called Asian crisis 1997/98 not only illustrates the spurification< of the concept of >natural market forces< but also shows how the latter is reflected in a growing technocratization of global financial market policy.

At the same time, financial markets cast a new light on the theory of reflexive modernization. Maybe they are not the exception that confirms the general rule that segments of society move from a first modernity to a second one. Rather, it seems as though the inability of financial market and the economy in general to reflect on their reflexivity is part of the fundament on which reflexive modernization is based. In that way, they become the blind spot of second modernity.

\section{Dirk vom Lehn}

\section{Die Kunst der Kunstbetrachtung: Aspekte einer Pragmatischen Ästhetik in Kunstausstellungen}

Der Artikel untersucht auf Basis von Videoaufnahmen und Feldbeobachtungen, wie Besucher Kunstwerke in gewöhnlichen und alltäglichen Museen betrachten. Er betrachtet die Interaktionsarbeit von Besuchern, die sich Ausstellungsstücke ansehen, während sie mit Begleitern oder anderen Besuchern im Museum interagieren. Die Analyse betrachtet soziale Interaktion als wesentlichen Einfluss für die Betrachtung und Wahrnehmung von Kunstwerken. Wie ein Kunstwerk gesehen wird, auf welche Aspekte Betrachter fokussieren und wie sie sie verstehen, ist nicht durch die Struktur des Werkes determiniert, sondern Ergebnis der sozialen Interaktion zwischen all denjenigen die sich in der unmittelbaren Umgebung des Objektes aufhalten. Besucher konfigurieren Betrachtungsräume vor den Kunstwerken und konstituieren die Aspekte der Werke, die sie betrachten, durch verbale Äußerungen, körperliche Handlungen und Gesten. Dabei bleiben sie sensibel für die Anwesenheit und Handlungen anderer Besucher. Sie passen ihre Verweildauer vor Exponaten und ihre Gehgeschwindigkeit durch die Ausstellung aneinander an und gestalten ihre Handlungen an den Kunstwerken so, dass eine Interaktionsordnung sichtbar wird, die als "pragmatische Ästhetik« (Knoblauch 1998) bezeichnet werden kann. Die >kunstvolle< Koordination der Handlungen vor den Kunstwerken ermöglicht den Vollzug einer relativ ungestörten Betrachtung der Objekte, auch wenn sich viele Besucher gleichzeitig im Museum aufhalten.

\section{The Art of Viewing Art. Aspects of a Pragmatic Aesthetics in Art Exhibitions}

The paper uses video-recordings and field observation to explore how people view artworks in ordinary situations in museums and galleries. It considers the interactional work that people undertake who have come to the museum on their own or with companions. The analysis reveals that social interaction critically influences how people view and make sense of artwork. How someone looks at and sees a piece of art, what particular aspects and features he looks at and how he understands them is not determined by the structure of the piece but arises in and through social interaction between all those in perceptual range of the object. People configure > view spaces< at artworks and constitute the aspects of the pieces that they look at through verbal, bodily and material actions as well as gestures. While interacting at the artwork visitors remain sensible to the presence and actions of others. They coordinate their 
dwell-time at exhibits and their pace through the galleries with others; and they design their actions at exhibits to provide each other with ways of seeing the artwork. Thus, an interaction order emerges that we characterise as »pragmatic aesthetics« (Knoblauch 1998). The artful coordination of visitors' actions facilitates the undisturbed viewing and appreciation of artwork, also when an exhibition is very busy.

\section{Anita Engels und Tina Ruschenburg}

\section{Die Ausweitung kommunikativer Räume: Reichweite, Mechanismen und Theorien der Globalisierung der Wissenschaft}

In der sozialwissenschaftlichen Literatur sind verschiedene Aspekte von Globalisierung und Denationalisierung kontrovers diskutiert worden. Dieser Artikel prüft nun empirisch für einen gesellschaftlichen Bereich (Wissenschaft) die Reichweite und die Mechanismen von Globalisierung sowie den Stellenwert von Nationalstaatlichkeit. Wissenschaft ist insofern ein spezifischer Fall, als ihr oft fraglose Globalität zugeschrieben wird, wogegen die Wissenschaftsforschung die Bedeutung ihres sozialen Kontextes betont. Die empirischen Daten stammen aus einer Fallstudie über 54 Umweltforschungseinrichtungen in Deutschland und den USA. Kern der Studie ist die Analyse von Koautorenschaftsmustern in ihren Publikationen zwischen 1993 bis 2002. Des weiteren werden die Selbstdarstellungen der Forschungsinstitute in ihren Internetauftritten sowie Interviews mit VertreterInnen der Institute sowie von Fördereinrichtungen ausgewertet. Die Publikationsdaten weisen auf eine begrenzte Ausweitung der Kommunikationsräume hin: Während sich ältere Kommunikationsmuster mit Industrieländern im Untersuchungszeitraum verdichten und auf Schwellenländer ausweiten, ist die Inklusion marginaler Regionen sehr viel schwächer ausgeprägt. Die Überprüfung der Denationalisierungsthese ergibt, dass der Stellenwert inländischer Kopublikationen nicht abnimmt. Auch in den Selbstbeschreibungen spiegelt sich zwar die globalisierte Weltsicht wider; dennoch steht die nationale Verortung im Vordergrund. Die Auswertung der Interviews zeigt vier wissenschaftsspezifische Mechanismen der Ausweitung kommunikativer Räume.

\section{The expansion of spaces of communication: on science globalization, its scope, its mechanisms and its theories}

Various aspects of globalization and denationalization are discussed in the social sciences' literature. This article focuses on the scope of and mechanisms for globalization with regard to one societal area (science) and discusses the importance of national contexts. Science is a specific case as it is often considered to be inherently global whereas Science Studies typically demonstrate effects of social contexts on the evolution of scientific knowledge. Empirical data used in this paper come from a study on 54 research institutions in Germany and the US. The analysis of co-authorship patterns is at the center of the study. It is combined with an examination of the mission statements of these institutions on their websites and with interviews held with heads of research institutions and representatives of funding agencies. Co-authorship data indicate a selective expansion of spaces of scientific communication. Established patterns of collaboration between OECD countries become denser and expand to threshold countries. The inclusion of marginal countries in developing regions, however, remains rather limited. Hypotheses of denationalization processes cannot be confirmed, as the density of domestic co-authorship patterns and the political relevance of the national context remain crucial for scientific communication. Finally, the interview sources are used to identify four different mechanisms for the expansion of spaces of scientific communication. 


\section{Thorsten Bonacker}

\section{Modernitätskonflikte in der Weltgesellschaft. Zur kulturellen Konstruktion globaler Konflikte}

Der Aufsatz schließt an die Diskussion um soziologische Theorien jenseits des sogenannten methodologischen Nationalismus an, der Gesellschaftsgrenzen mit nationalstaatlichen Grenzen gleichsetzt. Die Probleme eines solchen methodologischen Nationalismus zeigen sich besonders dort, wo sich die Entwicklung von Konfliktdynamiken seit 1945, spätestens seit Ende des Ost-West-Gegensatzes nicht mehr länger mit der Unterscheidung von internationalen und innergesellschaftlichen Konflikten angemessen verstehen lässt. Vor diesem Hintergrund wird erstens der Beitrag zweier neuerer makrosoziologischer Theorieansätze zur Erklärung der gegenwärtigen Konfliktkonstellation geprüft, die beide eine weltgesellschaftliche Perspektive einnehmen: zum einen die kulturalistische Theorie Shmuel Eisenstadts, zum anderen der Neoinstitutionalismus der Stanford-School um John Meyer. Kennzeichnend für beide Ansätze ist eine fundamentale Kritik an der mit dem methodologischen Nationalismus verbundenen Modernisierungstheorie. Darauf aufbauend wird dann, zweitens, die These entfaltet, dass die gegenwärtige Konfliktkonstellation sich der weitgehenden Entkopplung von Nationalstaatlichkeit und Modernität verdankt. Als Folge dieser Entkopplung zwischen der Moderne als kulturellem und politischem Programm und dem Nationalstaat als ihrer zentralen Institution entstehen Konflikte zwischen unterschiedlichen, miteinander konkurrierenden Gesellschaftsmodellen: dem globalen, dem nationalstaatlichen und subnationalen Modell. Dies wird anhand von empirischen Entwicklungen konkretisiert, wie etwa den Interventionsmöglichkeiten in Prozessen des Staatszerfalls.

\section{Conflicts on Modernity in World Society. On Cultural Construction of Global Conflicts}

The article is a follow up on the discussion on sociological theories beyond the so called »methodological nationalism « that equates borders of societies with national boarders. The problems of this methodological nationalism are particularly severe as the development of conflict dynamics since 1945 or at least since the end of the cold war cannot distinguish between international conflicts and conflicts in a society in an appropriate way. With this background the first task shall be to examine the use of two new macrosociological theories, which both use a perspective of world society for explaining contemporary conflict constellations: On one hand the cultural based theory of Samuel Eisenstadt and on the other hand the Stanford-school neo-institutionalism-theory based on the work of John Meyer. Characteristic for both is a fundamental criticism with the theory of modernisation. Secondly building up on the previous, the thesis of a far reaching separation between national statehood and modernity that grounds on the contemporary conflict constellation is displayed. As a result of this separation between modernity as a cultural and political programme and the national state as its dominant institution, conflicts arise between different competing models of society: the global, the national and the subnational model. This is demonstrated by some empiric development, for example the possibilities of intervening in the process of state collapse. 